\title{
Analysis and Evaluation of Environmental Management System Implementation in Indonesian Zoo
}

\author{
Sang Ayu Putu Thania Parameswari Eka Putri1 ${ }^{1}$, Rafika Yuniasih ${ }^{2}$ \\ 1,2 Universitas Indonesia, Depok, Indonesia
}

\section{INFO ARTIKEL \\ JEL Classification :}

M41, Q56

\section{Keywords :}

environmental management system, environmental management strategy, environmental management accounting, environmental management innovation, environmental management performance

\begin{abstract}
This study aims to analyze and evaluate the environmental management system implementation at Bali Zoo. This study was conducted using a case study method. Results show that Bali Zoo does not implement an environmental cost reporting based on environmental management accounting and has yet to focus on developing a competitive advantage on its resources based on the resource-based view theory. This study helps Bali Zoo in preparing environmental cost report to evaluate the efficiency of resources used in the environmental management and to integrate the concept of environmental management accounting in Bali Zoo's environmental management system.
\end{abstract}

\begin{abstract}
ABSTRAK
Penelitian ini bertujuan untuk menganalisis dan mengevaluasi penerapan sistem manajemen lingkungan pada Bali Zoo. Penelitian ini dilakukan menggunakan metode studi kasus. Hasil penelitian menujukkan bahwa Bali Zoo tidak menerapkan penyusunan laporan biaya lingkungan berdasarkan akuntansi manajemen lingkungan dan belum berfokus untuk menciptakan keunggulan kompetitif pada sumber daya berdasarkan resource-based view theory. Penelitian ini membantu Bali Zoo dalam penyusunan laporan biaya lingkungan untuk mengevaluasi efisiensi sumber daya alam yang digunakan dalam pengelolaan lingkungan serta sebagai bentuk integrasi konsep akuntansi manajemen lingkungan terhadap sistem manajemen lingkungan pada Bali Zoo.
\end{abstract}

\section{Introduction}

During these past decades, a plethora of environmental damages caused by the natural resource exploitation by various industries have become increasingly alarming (Rechkemmer et al., 2016). According to United Nations Environment Programme (2019), environmental degradation is not just bad for the natural world, but also for many people that jeopardize the sustainability of human life. In facing the challenge of creating a better environmental condition, the business world has created new values about environment in society by adopting an environmental management system, which is a strategic variable in company management (Llodra, 2006). Implementation of environmental management system, can help companies to reduce resource consumption, reduce negative impacts on the environment, and create better environmental conditions (Hsiao, Chuang, Kuo, \& Yu, 2014)

According to Ajayi \& Ayodele (2016), a zoo must use an environmental management 
system that can help identify, measure, and evaluate the impact of actions taken at the site. In 2017, Bali Zoo was recognized as The Best Conservation Institution by the Coordinating Ministry for Economic Affairs and Ministry of Environment and Forestry of the Republic of Indonesia (Antaranews.com, 2017). This award shows that Bali Zoo has managed the conservation area well, including the environment. As one of the best recreational and conservation spots, Bali Zoo is obliged to preserve its environment to avoid any negative impacts that might affect it (Zhong, Buckley, Wardle, \& Wang, 2015)

However, initial interview with the management of Bali Zoo show that environmental orientation is not the primary priority of company. Bali Zoo had not reported the environmental costs that are separated from their main financial statement until the end of 2019. In addition, Bali Zoo management also stated that environmental costs had always been included under the cost of sales, operating expenses, and other expenses, so they were unable to specifically classify the environmental costs and any expenses related to it. This condition is not in line with a study from Jalaludin, Sulaiman, \& Ahmad (2010) that stated business practitioners have put more attention towards business activities that negatively impact the environment. This is due to the significant increase in the environmental costs in relation to social obligation and environmental regulations for sustainable development. Therefore, organizations are required to collect, analyze, and report the environmental costs systematically in order to manage and control it. A study by Le \& Nguyen (2019) also found that company will be difficult to identify, measure, and evaluate how much environmental costs that had been incurred if environmental costs were combined with other accounts in financial statement. Thus, it is vital for a company to create a separate environmental cost report as a basis to evaluate their plans and take corrective actions to control such cost, reduce negative environmental impacts, as well as increasing financial efficiency.

To create a better environmental condition, one of the solutions for Bali Zoo to overcome this problem is to report their environmental costs in accordance with the environmental management system concept based on the resource-based view theory. This procedure will help the company to comprehend their own environmental costs, which consequently also assists them in evaluating the environmental performance to make decisions, measure the environmental impacts, and take other environmental initiatives.

This research aims to analyze and evaluate the implementation of the resource-based environmental management strategy at Bali Zoo, analyze and evaluate the environmental cost classification and environmental cost report using environmental management accounting at Bali Zoo, and analyze and evaluate the effects of resource-based environmental management innovation in creating competitive advantage in Bali Zoo's environmental management performance. Despite the importance of this problem, based on researchers knowledge, there is no other research that help a zoo as a recreational and conservation spot in designing environmental cost report based on environmental management system that is integrated with environmental management strategy, environmental management accounting, environmental management innovation, and environmental management performance.

\section{Literature Review}

\section{Resource-Based-View Theory}

The resource-based view theory was constructed with a view based on natural resource, which refers to the theory of competitive advantage built upon the relationship between company and environment (Hart, 1995). According to Almarri \& Gardiner (2014), the resource-based view theory is one of the most common theories used by company managers in project management to study how to create a competitive advantage from the company's resources.

\section{Environmental Management System}

Environmental Management System is a structured approach which is related to environmental aspects that can help a company in managing their activities' impacts towards the environment and showing a good environmental management (Ann, Zailani, \& Wahid, 2006). Based on a study by Iraldo, 
Testa, \& Frey (2009), environmental management system is a tool that is increasingly utilized in various sectors, driven by different certification schemes, such as ISO 14001 that focuses on environmental management system. This scheme gives a guarantee to related external parties regarding the environmental advantage and the company's commitment in enhancing its environmental performance.

\section{Environmental Management Strategy}

The concept of Environmental Management System must begin with Environmental Management Strategy which aims to create a competitive advantage resulting from the integration of company strategies with the development of company capabilities. A research by Kang \& He (2018) stated that environmental management strategy is a company's effort to achieve performance with special abilities in obtaining and allocating resources that depend on environmental orientation and innovation capability. A research by Cater, Prasnikar, \& Cater (2009) found that most of companies are environmentally responsible because of the personal commitment from the top management. Furthermore, it also reveals that public concern is a least important motive in implementing environmental management strategy, for the consumer's demands for the level of environmental friendliness is considered insufficient to be the main motives in practicing environmental strategy.

\section{Environmental Management Accounting}

According to IFAC's Management Accounting Concepts, environmental management accounting is an economic and environmental performance management through the development and environmentrelated accounting system and practices implementation, including life-cycle costing, benefits assessment, full-cost accounting, and strategic planning for environmental management (Jasch \& Savage, 2008). Environmental management accounting defined by Schaltegger, Viere, \& Zvezdov (2012) as an accounting framework that aims to understand deeper the economic and environmental information needed by company's decision makers and understand how internal information providers can meet these needs. In recent years, business interests in environmental management accounting have increased and have been promoted as a way for companies to manage environmental and economic performance more easily in achieving sustainable business (Christ \& Burritt, 2013). Environmental management accounting in this study focuses on environmental disclosure and environmental costs.

Environmental disclosure assists a company in showing their initiatives regarding environmental awareness, such as the development of eco-friendly products that gives the company an advantage point and competitive advantage in the future (Clarkson, Fang, Li, \& Richardson, 2010). In their study, Nor, Bahari, Adnan, Kamal, \& Ali (2016) state that companies contribute in disclosing their environmental activities in order to attract shareholders and fulfill the stakeholders' demands. However, Nwaiwu, (2018) study on oil and gas companies in Nigeria shows that environmental disclosure does not significantly affect the firms' performance as well as their return on capital employed (ROCE). Thus, this study endeavours to prove the effects of environmental cost disclosure as an implementation of Environmental Management Accounting towards a company's performance to fill the gap between the abovementioned studies' results.

According to Hansen \& Mowen (2015), environmental cost is required by a company as a basis for decision-making, especially related to environmental management. Classification of environmental cost is divided into four categories, which are environmental prevention cost, environmental detection cost, environmental internal failure cost, and environmental external failure cost.

\section{Environmental Management Innovation}

Porter in Ferreira \& Moulang (2010) states that innovation, or environmental management innovations in a company's environmental management is an important aspect for many businesses in creating a competitive advantage. Based on a study by Schiederig, Tietze, \& Herstatt (2011), a company's environmental strategies can be optimally actualized when they have environmental innovations to perform well. Those innovations include environmental innovations, ecological 
innovations, green innovations, and sustainable innovations.

\section{Environmental Management Performance}

Environmental Management Performance is measured by an index that assesses the environmental impacts on a company, where a company that actively administers a valueoriented environmental management strategy has a positive correlation with environmental performance and economy (Wagner \& Schaltegger, 2004). According to Schultze \& Trommer (2012), environmental management performance is considered as a multidimensional construction that includes environmental outcomes and impacts on companies, environment, and stakeholders. Environmental management performance also includes the principles of environmental responsibility as well as the environmental response process that determines future impacts.

\section{Research Model}

This study analyses and evaluates the implementation of environmental management strategy at Bali Zoo as an initial step that becomes the basis of environmental management accounting implementation. Thenceforth, it also analyses and evaluates the environmental management innovations dan environmental management performance as a result of environmental management system implementation at Bali Zoo. The environmental management system analysis and evaluation were conducted using the resource-based view theory in order to identify resources that can create a competitive advantage that is related to Bali Zoo's environmental management. The research framework is as follows.

\section{Figure 2.1 Research Model}

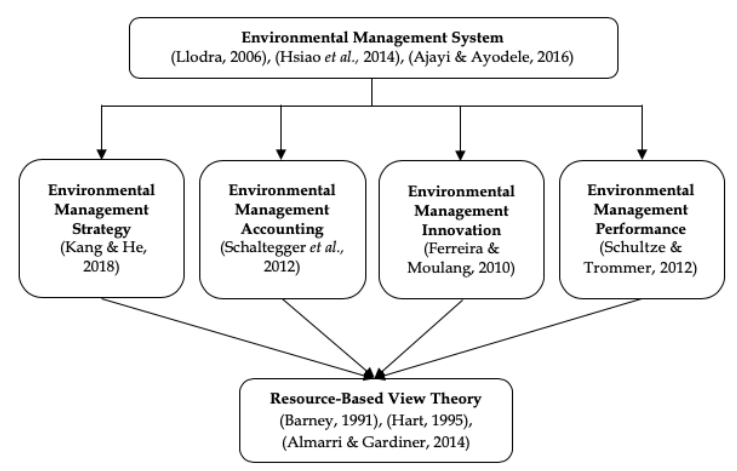

This study analyzes and evaluates the implementation of environmental management strategy at Bali Zoo as an initial step that becomes the basis of environmental management accounting implementation. Thenceforth, it also analyses and evaluates the environmental management innovations dan environmental management performance as a result of environmental management system implementation at Bali Zoo. The environmental management system analysis and evaluation were conducted using the resource-based view theory in order to identify resources that can create a competitive advantage that is related to Bali Zoo's environmental management.

\section{Research Method}

This study uses a single case study approach where it focuses on one phenomenon. Case study is the right method to answer certain phenomena or research problems deeply (Biswan \& Widianto, 2019). This study uses case study to explore deeper research phenomena, as well as add insight into the occurrence of these phenomena. A case study was conducted at Bali Zoo, one of Indonesian zoos that does make an environmental cost report separately from their main financial statement. A case study is aimed to examine a phenomenon comprehensively and deliberately using research questions at Bali Zoo.

The data originated from primary data that were collected through interviews and documentation. Primary data is data obtained directly from related company or termed as private domain. The interviews were conducted on a number of interviewees whose jobs are related to Bali Zoo's environmental activities. The consideration in determining interviewees because they are directly involved in the company's environmental activities, including operational activities related to the environment, preparation of annual financial reports, and the preparation of environmental program and policy reports. They were Bali Zoo's Head of Accounting, Assistant of Accounting Manager, Project Manager, and Operational Manager. Moreover, the documentation was conducted on the Annual Financial Report, Environmental Program and Policy Report, and Environmental 
Management Plan and Environmental Monitoring Plan Report of Bali Zoo.

The data analysis of this study was conducted using descriptive analysis and content analysis. Descriptive analysis is used in this study to express a deep understanding of the application of the environmental management system at the Bali Zoo and its translation in the form of environmental management strategy, environmental management accounting, environmental management innovation, and environmental management performance. Content analysis in this research is used to analyze the results of interviews and documentation by analyzing the interviewees and documents' words that are related to the research problems and resourcebased view theory. The interview was analyzed per respondent, and the documentation result analysis was categorized into management and monitoring of resources that have impacts on Bali Zoo environment as a part of the study's main topic, which is environmental management system implementation. Based on the content analysis result, the researchers was able to draw an objective conclusion on the environmental management system implementation of Bali Zoo

General description of the steps of qualitative data analysis in this study follows the steps of Creswell (2014), including organized and prepared data for analysis, read the entire data, started coding data, used the coding process to produce situation descriptions and themes to analyze, represented descriptions and themes in the form of qualitative narratives, and interpreted data in qualitative research. Data testing in this study includes reliability and validity test that refers to Creswell (2014). The reliability testing procedures used are checking the results of the transcription to ensure there are no errors in the transcription process and ensuring there are no shift in meaning during the coding process. Meanwhile, the validity testing procedures used are triangulation, reference material, and member checking.

\section{Result and Discussion}

Bali Zoo's environmental management system begins with the guidance of environmental policies from the Central Government, Regional Governments, and other relevant bodies that must be complied by the company. The environmental policy that Bali Zoo must comply with in order to meet environmental management requirements is Government Regulation of the Republic of Indonesia Number 27 of 1999 concerning Analysis of Environmental Impact Assessment and also Decree of the Minister of Environment and Forestry of the Republic of Indonesia Number 86 of 2002 concerning Guidelines for Implementing Environmental Management and Environmental Monitoring Efforts. After Bali Zoo identifies environmental policies that are used as company guidelines, then they implements the environmental management system through the environmental management stage in the form of designing an environmental strategy to provide information about operational activities that have important impacts on the environment, environmental management efforts undertaken, and management results obtained by the company.

Environmental management is carried out by the Operational Department as the department most frequently associated with the Bali Zoo environment. The next stage is the environmental monitoring stage, where the Operational Department is responsible for monitoring the realization of environmental management efforts that have been previously designed. Environmental monitoring is a stage to provide information about the environmental impacts that are monitored, parameters that are monitored, and the results of monitoring. The environmental management and monitoring at Bali Zoo are focused on liquid waste, hazardous and toxic waste, animal waste, rubbish, and exhaust and noise emissions.

Based on the results of environmental management and monitoring activities that have been carried out, an evaluation is then conducted by the Operational Department that is physically responsible for the environment accompanied by the Legal and General Affairs Officer that is responsible for making evaluation reports on environmental management and monitoring conducted by Bali Zoo. The evaluation was carried out on the level of compliance with the implementation of activities to meet the various provisions contained in the Environmental Management Efforts and Environmental Monitoring Efforts 
Report (UKL-UPL) required by the Forestry and Environmental Service of Bali and the Environmental Service Office of Gianyar Regency. Thenceforth, an evaluation report based on the management and monitoring at Bali Zoo's environment was made. The stages of the environmental management system in Bali Zoo are summarized in the flow shown in Figure 4.1.

Figure 4.1 Bali Zoo's Environmental Management System Implementation

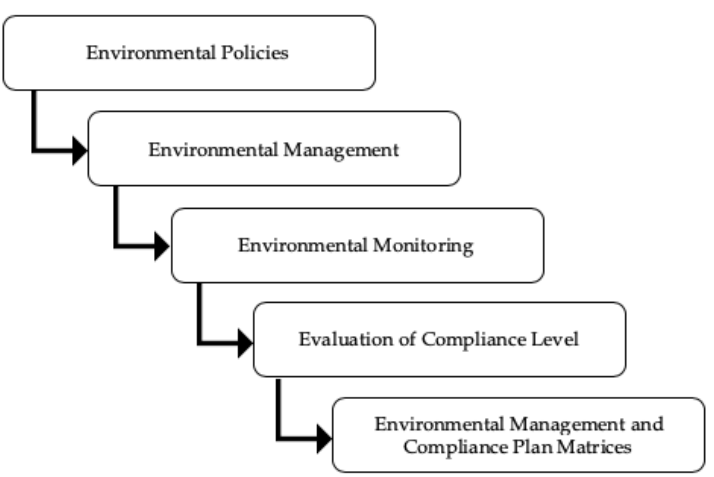

Source: Processed Data (2020)

\section{Resource-Based Management Strategy at Bali Zoo \\ Environmental}

The Environmental Management Strategy was prepared by Bali Zoo because all company activities come into contact with humans and animals, so these activities must not endanger existing animals, especially must not to endanger humans as workers who are the company's most important resource. Bali Zoo shows its sincerity in carrying out development activities and operations of the Environmental Conservation and Parks Institute, as well as participating directly in the development of sustainable areas in accordance with the company's commitments and policies in the environmental field.

Several environmental management strategies implemented by Bali Zoo include clean water usage, liquid waste management, hazardous and toxic waste management, solid waste (rubbish) management, animal waste management, and exhaust and noise emission management. The clean water for operational activities of Bali Zoo is sourced from the City Water Service and Ground Water authorized by the One-Stop Permit Services Board of Gianyar Regency of as much as $20 \mathrm{~m}^{3}$ per day. Considering that the demand for clean water as a resource keeps increasing, Bali Zoo always complies with the Government's regulation regarding ground water pumping. This is an effort to prevent an aggressive water pumping that can cause contamination and decrease in ground water flow rate.

For the liquid waste, an effort to minimize negative environmental impacts is done by storing the waste from restaurant, animal cage cleaning, and toilet inside a vessel namely ground tank, with different vessel for each type of liquid waste. This liquid waste management is carried out by a third party by clearing the waste in the vessels once to thrice a week, depending on the number of visitors. Meanwhile, liquid waste from elephants' bathing pool is managed using aeration and filtration process by Bali Zoo independently, where the pool water is filtered before channeled using water pipe to be used as the elephants' bathing water and to water the plants. Such aeration and filtration process are done to save more water from the City Water Service and ground water pumping, allowing it to be reusable and not contaminative towards the environment.

In addition to liquid waste, Bali Zoo also generates hazardous and toxic waste and solid waste. Hazardous and toxic waste such as syringe and needles for animals, used battery, accumulator, cotton or bandage, injection medicine bottles, lamps, and oil are collected and given to a third party who is permitted to collect and transport such materials. This does not comply with the Article 10 of the Government Regulation of the Republic of Indonesia Number 101 of 2014 on the Hazardous and Toxic Waste Management which states that "every individual that generates hazardous and toxic waste shall dispose the waste through substance substitution, process modification, and/or the use of eco-friendly technology." Bali Zoo also does not record the amount and type of generated hazardous and toxic waste, so their environmental management strategy cannot be executed optimally. The solid waste (organic and non-organic) are stored in Bali Zoo's temporary waste disposal site before transferred by a third party to the final waste disposal site.

The management of animal waste, especially elephants', is done independently by 
Bali Zoo by processing it into organic fertilizer for plants within the zoo premise. The rationale behind this treatment is because elephant is herbivorous whose excrements contain good fibers that fertilize plants. Additionally, elephants' feces are big in volume and odorless. This waste drying process is still using a traditional method with no special equipment and has become one of Bali Zoo's strategies to economize in purchasing plant fertilizers. Furthermore, Bali Zoo conducts a strategy for managing exhaust and noise emissions originating from generators includes collaboration with the Office of Manpower and Entity of Transmigration Settlement. However, monitoring of the noise level has never been done because the frequency of operation of the generator set is very rare.

A monitoring system is compulsory in the execution of those aforementioned strategies in order to achieve the set forth targets. Bali Zoo has policies and commitments in terms of environmental protection, as well as efficiency and conservation of resource. Therefore, it creates a safe work environment for the staff, a conserved habitat for the animals, and it prevents detrimental impacts from harming the environment. The environmental management strategy of Bali Zoo is the form of efforts to utilize and allocate resources to improve the environmental management performance, which later influences the financial performance, as also stated by Hart (1995) in his study. These strategies have maximized internal strengths in the forms of the human resources' ability to manage the waste, take opportunities on the external environment, minimize external environment threats and complaints from visitors, and minimize internal environment weaknesses by conserving the animal habitats as the main business focus of Bali Zoo.

The environmental management strategy undertaken by Bali Zoo is an effort to use and allocate resources to improve environmental performance that will have an impact on improving financial performance as revealed in Hart (1995) research. In carrying out its environmental management strategy, Bali Zoo focuses on aspects of natural resources and human resources. A natural resource-based environmental management strategy has been carried out by Bali Zoo in the form of compliance with groundwater pumping, reuse of processed wastewater products to conserve water use, and reuse of processed animal waste products to conserve plants around the public area. In addition to the aspect of natural resources, the human resource aspect is also a major element in decision making with respect to environmental management strategy in business activities carried out by Bali Zoo. This is consistent with the statement of Operational Manager as follows.

"In my opinion, human resources in Bali Zoo are very important. Bali Zoo is an animal park that is in direct contact with animals and the environment that resembles its habitat, so that human resources must have adequate skills with regular training. For example, keepers for each type of animal. The position does not have a special academy, but they must participate in training while working here. We train human resources here according to international standards. All forms of training are what we are intensifying here. Even though the expenses are quite high, it is an investment for the continuity of the Bali Zoo business" (Dedi).

The interview quote above shows that Bali Zoo prioritizes aspects of human resources in carrying out its business activities and has invested in human resources training to comply established standards. Bali Zoo management emphasizes that formal education is not enough to make Bali Zoo employees to be resources that have adequate capabilities that are needed by company. However, Bali Zoo employees must be given special training on a regular basis to increase their soft skills and environmental awareness that can provide value added to the company.

In addition to Operational Manager, the Project Manager also stated that human resources are the key to the success of Bali Zoo's environmental management performance. This is stated in the following quote.

"In 2017, there was a problem of environmental pollution in one of our restaurants. There was an error in the system and an error in calculating the volume of liquid waste, so that the liquid waste flowed into the river without being accommodated in the ground tank or treated further. This problem actually occurs due to human resources errors. At the time, the kitchen staff were not sufficiently interacted and did not carry out the Standard Operating Procedure (SOP) that they 
should. Therefore, Bali Zoo always holds training in the aftermath of the problem. The key to company success is our human resources. No matter how well the SOP has been designed, if human resources is unable to implement it, then the work will not be carried out properly either" (Eka).

The interview results show that education and training on human resources is a solution to resolve Bali Zoo's environmental problems that have occurred in 2017. The aspect of human resources is a very important for company's activities, including environmental activities. Therefore, human resources are an important element in formulating a good and quality Bali Zoo environmental management system so that all environmental management activities are carried out in a planned manner, in accordance with applicable standards, and in accordance with company needs. This is in line with resource-based view theory in the research of Almarri \& Gardiner (2014) which stated that in forming competitive advantage, companies must be able to identify the resources and management capabilities, because the ability of the resources owned is very important for maximizing the company's potential. Based on the presentation of the company's steps in carrying out its environmental strategies that is integrated with resource-based view theory, this study concludes the scheme of environmental management strategy implementation in Bali Zoo in Figure 4.2.

Figure 4.2 The Scheme of Environmental Management Strategy in Bali Zoo

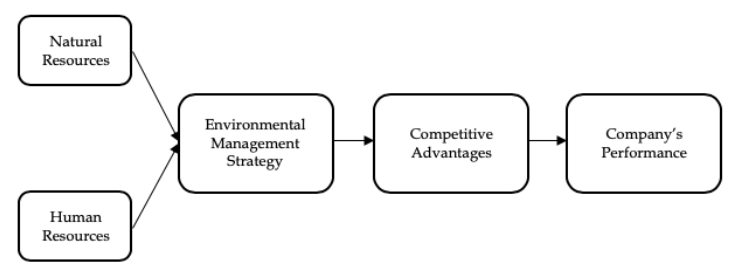

Source: Processed Data (2020)

\section{Environmental Cost Classification And Environmental Cost Report In Environmental Management Accounting Implementation At Bali Zoo}

The Planning Of Bali Zoo's Environmental Management Strategy Does Not Use Environmental Management Accounting As Its Basis Of Decision-Making And
Environmental Management Innovation. The Interview Results Show That Bali Zoo Management Does Not Have The Knowledge Related To Environmental-Based Accounting Reporting And Does Not See The Urgency Of Environmental Management Accounting Implementation. This Was Revealed By The Head Of Accounting In The Following Interview Quote.

"We Do Not Understand Yet About The Concept Of Environmental Management Accounting Because We Have Made Financial Reports In General So Far. Actually, We Incur These Environmental Costs. But We Recorded It In General Financial Statements Accounts, For Example The Cost Of Cleaning Up Liquid Waste To Operating Expenses, And Others. In This Case, If There Is A New Environmental Strategy, We Will Create The Budget And If There Are Problems With Environmental Pollution, We Will Also Immediately Overcome Them. All Costs Are Included In The Income Statement" (Komang).

The Interview Quote Above Shows That Bali Zoo Did Not Apply The Concept Of Environmental Management Accounting In The Company's Planning And DecisionMaking Process Regarding Strategy And Innovation In Overcoming Environmental Problems. Although Bali Zoo Involves Developing Aspects Of Human Resources That Support The Company's Environmental Sustainability In Its Environmental Management Strategy, But Until Now Bali Zoo Has Not Trained Its Human Resources Specifically To Understand Environmental Management Accounting. This Is Also In Line With The Statement Of Assistant Of Accounting Manager Of Bali Zoo Contained In The Following Quote.

"For The Environmental Costs Budget And The Realization Of Its Use, We Have Not Made A Special Report. We Know The Environmental Expenses By The Operational Department, For Example, Maintenance Of The Garden Area, Pay For Disposal Of Waste To Third Parties, Clean The Animal Ponds, Etc., But We Recorded All These Costs In To The Cost Of Sales, Operating Expenses, Or Other Expenses Each Month" (Saras).

Based On The Results Of The Interview, Bali Zoo Does Not Know Which Costs Are Included In The Classification Of 
Environmental Cost Because There Are No Human Resources From The Accounting Department That Have Expertise In Environmental Management Accounting. Another Respondent, Operational Manager, Also Added His Opinion Regarding The Allocation Of Environmental Cost As Follows.

"For Costs Related To The Environment, We Usually Allocate In The Budget If At Any Time Environmental Problems Happen. For Example, When Liquid Waste From Restaurants Polluted The Rivers And The Unpleasant Odor From Animal Pond Waste Disturbed Visitors, We Immediately Use The Budget To Clean The Environment. But In Essence, We Don't Make Separate Allocations Specifically For The Environment, Just The Budget Per Area, For Example The Budget For The Maintenance Of The Restaurant, Budget For The Maintenance Of The Elephant Pool, Etc." (Dedi).

The statement of Operational Manager shows that Accounting Department actually has details of environmental expenditure, but these cost details are recorded in other accounts, so Bali Zoo cannot identify total Environmental Costs Incurred So Far And Cannot Assess The Effectiveness Of Activities Relating To The Environment As A Basis For Making Decisions To Improve Environmental Management Performance. Bali Zoo Also Does Not Have A Special Account Of Environmental Costs Because There Has Been No Classification Of Environmental Cost Components Since The Beginning Of The Bali Zoo Established Until Now. In Addition, Assistant Of Accounting Manager Of Bali Zoo Also Stated About For Environmental Budget Evaluation In Bali Zoo In The Following Quote.

"We Did An Evaluation Of Company's Expenses, But We Don't Know Which Costs Are Classified Into The Environmental Costs. However, For The Evaluation Of Costs Associated With Waste, For Example A Septic Tank For Suctioning Wastewater, We Have Searched For 3 Comparisons Of Third-Party Services. Because It Is Used Routinely, So There Must Be A Comparison Which Is The Cheapest Price. This Includes Solid Waste Transportation Services. Some Time Ago, Rubbish Were Transported Using A Colt Car. But Now, We Use A Truck To Accommodate A Bigger Volume Of Waste" (Saras).
The Interview Quote Above Shows That Bali Zoo Has Evaluated The Environmental Costs By Prioritizing Cost Efficiency And Company Needs. However, Bali Zoo Does Not Classify Environmental Costs Based On Four Cost Classifications According To Hansen \& Mowen (2015) So They Cannot Assess The Effectiveness Of Activities Related To The Environment As A Basis For Making Decisions To Improve Environmental Management Performance Going Forward. Environmental Management Accounting Implementation Is Crucial To Analyze And Use Monetary And Non-Monetary Information. Without Implementing Environmental Management Accounting, Bali Zoo Cannot Manage And Utilize The Capabilities Of Their Human Resources Maximally.

The Implication Is The Lack Of Awareness About The Environmental Cost And How It Benefits Bali Zoo Per Se. Therefore, Thus Far, Bali Zoo Has Not Reported All Activities And Environmental Cost Components In A Detailed Manner In Their Annual Financial Statement. It Will Be Difficult To Actualize Bali Zoo's Commitment To Improve Their Environmental Performance And Create Environmental Competitive Advantages Without Implementing Environmental Management Accounting In Planning The Environmental Strategies And Innovations. This Is In Line With A Study By Christ \& Burritt (2013) That Mentioned Environmental Management Accounting Has Been Promoted As A Way For Companies To Manage Environmental And Economic Performance More Easily In Achieving Sustainable Business.

Without The Application Of Environmental Management Accounting At Bali Zoo, It Shows That The Company Has Not Managed And Utilized The Capabilities Of Its Human Resources, Resulting In A Lack Of Knowledge Regarding Environmental Cost Report And It's Usefulness For Company. Therefore, Bali Zoo Has Not Been Able To Compile A Report Detailing All Activities And Environmental Cost Components To Date. According To Stanojevic, Vranes, \& Gokalp (2010) One Of The Good Environmental Strategies In Overcoming Environmental Negative Impacts Is By Disclosing And Categorizing Environmental Costs Based On 
Their Utilization Using Environmental Accounting Concept.

In addition, the impact of the application of environmental management accounting will also impact by Bali Zoo in terms of business process innovation, such as improvements in business processes, cost reduction, reputation improvement, and decision making. In line with Abdullah \& Yuliana (2018), the disclosure of environmental activities and the presentation of environmental costs have a positive impact on environmental management performance of companies. The disclosure of environmental costs also has an impact on increasing the company's commitment to environmental improvement, as an effort to realize sustainable development. Therefore, Bali Zoo needs to implement a good environmental management strategy to overcome various environmental problems that arise. One of which is by disclosing and categorizing environmental costs in accordance with their use using the concept of environmental-based accounting.

Presentation of environmental costs begins with the process of identifying costs based on environmental management activities that have been described previously. In this case, the data used by researchers to identify environmental costs is the 2018 Bali Zoo Annual Financial Report, because it is the last year report that was completed by Bali Zoo at the time the research was conducted. The identification of environmental cost components is done by researchers based on the source of costs for environmental management activities that have been carried out. The proposed classification of environmental costs by source is designed based on the results of the 2018 Bali Zoo Annual Financial Report, which is adjusted to the results of interviews about the company's environmental management strategy. The proposed environmental cost components based on the source of funds submitted to Bali Zoo showed in Table 4.1.

Based on Table 4.1, total environmental cost that Bali Zoo spent in 2018 was $\mathrm{Rp} 2.602 .075 .784$. The categorization of the environmental costs above was classified based on the source of activities that might possibly impact the environment. Those activity sources are based on the environmental management strategies that Bali Zoo has, which are clean water usage, liquid waste management, hazardous and toxic waste management, solid waste (rubbish) management, animal waste management, exhaust emission and noise management, and others.

Table 4.1 Environmental Cost Components of Bali Zoo

\begin{tabular}{|c|c|c|}
\hline Source of Cost & Cost Type & $\begin{array}{l}\text { Environmental Cost } \\
\text { (IDR) }\end{array}$ \\
\hline \multirow{4}{*}{$\begin{array}{l}\text { Clean Water } \\
\text { Usage }\end{array}$} & Underground Water Construction Project & 4.608 .000 \\
\hline & Ground Water Pumping & 5.412 .970 \\
\hline & $\begin{array}{l}\text { Ground Water Tax } \\
\end{array}$ & 2.234 .381 \\
\hline & Clean Water Quality Checkup & 1.250 .000 \\
\hline \multirow[t]{4}{*}{ Liquid Waste } & $\begin{array}{l}\text { Elephant Pool Pipes and Pump } \\
\text { Installation }\end{array}$ & 2.750 .000 \\
\hline & Animal Pool Water Quality Checkup & 1.825 .000 \\
\hline & Animal Pool Maintenance and Sanitation & 14.670 .000 \\
\hline & $\begin{array}{l}\text { Liquid Waste Cleaning Service Fee by } \\
\text { Third Party }\end{array}$ & 38.280 .000 \\
\hline $\begin{array}{l}\text { Hazardous and } \\
\text { Toxic Waste }\end{array}$ & $\begin{array}{l}\text { Hazardous and Toxic Waste } \\
\text { Transportation Cost by Third Party }\end{array}$ & 6.000 .000 \\
\hline & Cleaning Service and Temporary Waste & 7.453 .600 \\
\hline \multirow{2}{*}{ Waste/Rubbish } & $\begin{array}{l}\text { Disposal Site Fee } \\
\text { Public Area Cleaning Service Fee }\end{array}$ & 31.286.339 \\
\hline & Waste Transportation Cost by Third Party & 10.232 .328 \\
\hline Animal Waste & Animal Cage Maintenance and Sanitation & 802.329 .689 \\
\hline Exhaust and & Genset Management & 15.591 .928 \\
\hline Noise Emission & Ground (Genset Area) Leveling & 42.750 .000 \\
\hline \multirow[t]{8}{*}{ Miscellaneous } & Garden Management & 35.500 .000 \\
\hline & $\begin{array}{l}\text { Garden Repair } \\
\end{array}$ & 17.350 .000 \\
\hline & Zoo Area Repair & 1.483 .059 .884 \\
\hline & Plant Relocation & 6.020 .000 \\
\hline & Garden Inventory Depreciation & 12.308 .825 \\
\hline & Trees and Plants Depreciation & 50.097 .840 \\
\hline & $\begin{array}{l}\text { Operational and Conservation Staff } \\
\text { Training }\end{array}$ & 11.065 .000 \\
\hline & Total Environmental Cost & 2.602 .075 .784 \\
\hline
\end{tabular}

Source: Processed Data (2020)

The account names for each of these expenses have been adjusted by researchers based on the terms that best suit environmental management activities. This is in line with the research of Le \& Nguyen (2019) which stated that the first solution in recording environmental costs is to make accounts clearly. These accounts will make it easier for management accountants to collect, measure, and monitor environmental costs. The costs were further categorized into four types of environmental cost according to Hansen \& Mowen (2015). Those four types are environmental prevention cost, environmental detection cost, environmental internal failure cost, and environmental external failure cost shown in Table 4.2.

Table 4.2 shows the suggested classification of environmental cost based on the 2018 Annual Financial Statement of Bali Zoo. Bali Zoo did not have any cost for the environmental external failure in 2018. This was according to the statement from Bali Zoo management, saying that environmental issues had never reached any external parties, and 
there had been no complaints from the community around Bali Zoo that obliged the management to settle the matter. Based on the results of interviews, several environmental problems that had an impact on the external environment had occurred before 2018 .

Table 4.2 Classification of Environmental Cost of Bali Zoo

\begin{tabular}{l}
\hline \multicolumn{1}{c}{ Environmental Prevention Cost } \\
\hline Underground Water Construction Project \\
\hline Ground Water Pumping \\
\hline Ground Water Tax \\
\hline Elephant Pool Pipes and Pump Installation \\
\hline Animal Pool Maintenance and Sanitation \\
\hline Liquid Waste Cleaning Service Fee by Third Party \\
\hline Hazardous and Toxic Waste Transportation Cost by Third Party \\
\hline Cleaning Service and Temporary Waste Disposal Site Fee \\
\hline Waste Transportation Cost by Third Party \\
\hline Animal Cage Maintenance and Sanitation \\
\hline Genset Management \\
\hline Ground (Genset Area) Leveling \\
\hline Garden Management \\
\hline Garden Repair \\
\hline Trees and Plants Depreciation \\
\hline Operational and Conservation Staff Training \\
\hline Environmental Detection Cost \\
\hline Clean Water Quality Checkup \\
\hline Animal Pool Water Quality Checkup \\
\hline Environmental Internal Failure Cost \\
\hline Public Area Cleaning Service Fee \\
\hline Garden Repair \\
\hline Zoo Area Repair \\
\hline Plant Relocation \\
\hline Environmental External Failure Cost \\
\hline
\end{tabular}

Source: Processed Data (2020)

This shows that in 2018, Bali Zoo had a high concern for the environment and good motivation in complying environmental management standards. The next stage is to compile and present an environmental cost report that can be used as a basis or format for the preparation of reports in the next period with the aim of helping Bali Zoo management decisions related to the environment. The researchers' proposal for the 2018 Bali Zoo Environmental Cost Report based on the environmental cost classification that has been designed in Table 4.3.

Table 4.3 shows that the total environmental cost that Bali Zoo spent in 2018 was $7,22 \%$ of total operating cost, with each percentage are $2,95 \%$ for environmental prevention cost, $0,01 \%$ for environmental detection cost, and $4,27 \%$ for environmental internal failure cost. If measured from the total environmental costs that occurred in 2018, the percentage of each classification of Bali Zoo's environmental costs can be seen in Figure 4.1.

Based on the 2018 Environmental Cost Report of Bali Zoo presented in Table 4.3 and the percentage of environmental costs presented in Figure 4, it can be seen that the environmental prevention cost has a significant portion because Bali Zoo has a variety of activities in environmental management related to the environmental management strategy.

\section{Table 4.3 2018 Environmental Cost Report of Bali Zoo}

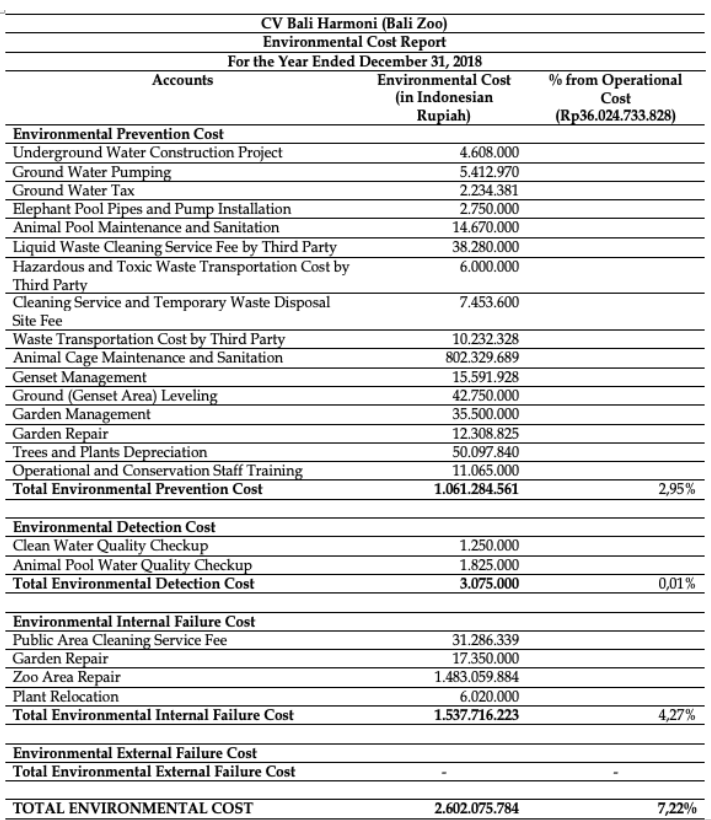

Source: Processed Data (2020)

Figure 4.1 Percentage of Bali Zoo's Environmental Costs

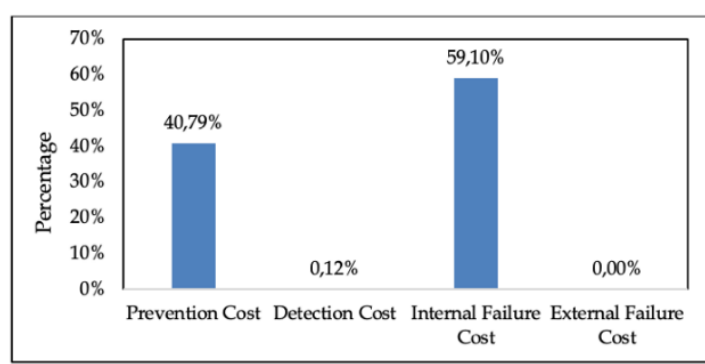

Source: Processed Data (2020)

In addition, activities that increase the environmental prevention cost in addition to the routine activities of the Bali Zoo in 2018 are the construction of groundwater pipes, installation of pipes and pumps for elephant ponds, leveling of the genset area, and training costs for conservation and operational staff. This shows that the expenditure of environmental costs in Bali Zoo is used to improve the performance of natural resources in the form of groundwater use, animal habitat management, and land management for generators in order to prevent disruption due to 
exhaust gas emissions. In addition, the expenditure of environmental costs at Bali Zoo also aims to invest in human resources including training of staff in the Conservation and Operational Departments that are directly in contact with the environment and animals. Therefore, based on the percentage of environmental prevention costs, it can be concluded that Bali Zoo has made maximum efforts to prevent environmental pollution due to pollution, waste, or garbage that can damage the environment.

The percentage of environmental detection cost is very low compared to environmental prevention cost and environmental internal failure cost of the environment. This happens because of the minimum environmental detection activities carried out by Bali Zoo, which only focuses on checking the quality of ground water and aquatic pond water only. Meanwhile, Bali Zoo did not measure noise and emissions and exhaust gases which should be one of the activities to ascertain whether the process of using the engine complies with environmental standards or not. In addition, Bali Zoo should also conduct monitoring activities on the effectiveness of other environmental management processes, such as monitoring of hazardous and toxic waste management, liquid waste, animal waste, and solid waste or rubbish, in order to ensure that all processes comply with environmental standards that have been set.

Meanwhile, the environmental internal failure cost has the highest allocation of the total environmental costs incurred by Bali Zoo. The expenditure is dominated by the improvement of the zoo's environment which costs amount to Rp1.483.059884. One of the improvements to the zoo's environment is to improve the condition of several animal habitats and their sewage disposal, so that the time to clean up can be shortened so that conservation staff can use time more effectively. In 2018, a development project were carried out to expand the wastewater collection basin as a solution to the full problem of the reservoir before being sucked up by a third party and as a first step for the Bali Zoo to start managing its own liquid waste without a third party.

Environmental improvements were also carried out in the restaurant area precisely at the location of the restaurant's liquid waste collection so that the waste does not emit a bad odor in the visitor's area. The cost of this internal environmental failure was also incurred for cleaning public areas, repairing gardens, and removing plants which showed that Bali Zoo spent a lot of money to improve environmental conditions and eliminate environmental problems that had occurred but had no impact on the external environment the zoo. For the environmental external failure cost, there is no expenses recorded by Bali Zoo during 2018. As explained earlier, in 2018 there were no any environmental problems that impacted on external parties and there were no complaints of negative impacts from companies outside the zoo.

Based on the analysis of the four Bali Zoo environmental cost classifications according to Hansen \& Mowen (2015), it can be concluded that the total cost to improve and recover environmental conditions including the environmental internal failure cost is greater than the total cost to prevent negative environmental impacts including environmental prevention cost and environmental detection cost. Therefore, Bali Zoo have to focus on the environmental prevention cost and primarily environmental detection cost to optimally increase environmental prevention activities through various innovations and create sustainable environmental condition.

\section{The Effects of Resource-Based Environmental Management Innovation on the Competitive Advantage and Environmental Management Performance of Bali Zoo}

One of the environmental management innovations that was done by Bali Zoo is the investment on a liquid waste management system, namely the Sewage Treatment Plant. Sewage Treatment Plant is a liquid waste management system that separates contaminative substance using a biologic system to clean water. Consequently, Sewage Treatment Plant can be used to manage liquid waste from restaurant kitchen, and it serves to dissolve fat in fluids, especially in fatty food waste. Sewage Treatment Plant was developed by Bali Zoo in early 2020. Bali Zoo said that 
the investment in the Sewage Treatment Plant system required a very large cost. This can be seen in the following interview quote of Bali Zoo's Project Manager.

"Previously, to clean up liquid waste in restaurants, we used a tank system that had to be taken every month on a regular basis by a third party. At that time, we did not have a system. But now we have installed a Sewage Treatment Plant, which we have always dreamed of. Our consideration at that time was high installation costs and additional costs for the human resources. But finally, at the beginning of 2020 we have installed the equipment and systems. The cost of the equipment itself is around Rp200 million, plus the system is around Rp100 million" (Eka).

Based on the statement above, it can be seen that Bali Zoo has planned to make innovation using Sewage Treatment Plant in its waste treatment before 2020, but they still consider the total costs to be incurred. Finally, in the beginning of 2020, Bali Zoo has succeeded in creating their environmental management innovation. The innovation of this system has allowed Bali Zoo to reuse the water after being processed by Sewage Treatment Plant for the purpose of watering plants and toilet flushing within the area of the zoo. Eventually, the water can be released to a river close to Bali Zoo in a clean condition as well. This has saved up a considerable amount of clean water resource, for it can be reused without exploiting more natural resources. Moreover, Bali Zoo also will save up the cost for monthly liquid waste management and control cost. In other words, innovations along with a competent human resource and sufficient natural resource encourage a company to create its competitive advantage.

Another environmental management innovation undertaken by Bali Zoo is to build a ground tank for treatment of liquid waste that is larger than the previous storage tank that aims to conduct its own wastewater treatment without a third party. Innovations in the form of an expansion of the ground tank began in mid-2018 and the project was completed in the early mid-2019. However, the Bali Zoo began to conduct wastewater treatment independently accompanied by an investment in the Sewage Treatment Plant system. Therefore, the realization of independent wastewater treatment began in early 2020. The benefit gained from such innovation is the cost savings in managing and controlling liquid waste that is released every month, so it can be concluded that innovation and strong ownership of human and natural resources will encourage companies to create competitive advantage. This in in line with a study from Ferreira \& Moulang (2010) that stated that an important aspect for most businesses in creating competitive advantage is innovation.

Bali Zoo mainly invests in liquid waste management system with both financial and non-financial benefits. Financially, Bali Zoo is able to cut up the cost for plant watering and toilet flushing due to recycle procedure. Bali Zoo does not have to spend more on the cleaning service fee caused by liquid waste that contaminate the environment around Bali Zoo internally and externally. Non-financially, Bali Zoo does not have to deal with complaints and protests regarding pollution from their staff, visitors, and the community around. This is in line with a study of Inoue, Arimura, \& Nakano (2013) that stated environmental management innovation have contributed as a means to create corporate competitiveness while reducing environmental pressures.

Bali Zoo management stated that the environmental performance from those innovations are satisfactory, proven by the diminutive amount of pollution or any other issues that come externally, such as complaints from various parties. On top of that, Bali Zoo was awarded the Best Conservation Institution in Indonesia by the Ministry of Environment and Forestry of the Republic of Indonesia and 2014 Travelers' Choice by Trip Advisor. Bali Zoo management believes that by complying with the Government's regulation alone, their environmental performance can be deemed decently well even without any innovation.

However, Schiederig et al. (2011) argue that a good environmental performance is the result of environmental strategies that are accompanied by environmental management innovation. Furthermore, Bali Zoo also does not establish a clear standard in regards to environmental performance achievements. This can also increase the internal and external transparency about the company's operational activities related to environment and their impact mitigation plans. Ergo, it can be concluded that Bali Zoo's environmental management performance assessment thus far 
has not yet to be a good parameter of environmental performance achievements. This is because Bali Zoo believes that their innovations are already in line with the Government's regulations, and that they are considered good by viewing it from the achieved environmental management performance.

\section{Conclusion}

The environmental management strategy that is done by Bali Zoo is not based on the concept of environmental management accounting, in which the human resources have no related knowledge about environmentbased accounting report. Thus, based on the resource-based view theory, Bali Zoo is not focused on creating a competitive advantage on their human resources in managing the environment. In terms of environmental management innovations, Bali Zoo has invested in a liquid waste management system that is beneficial both financially and nonfinancially. The environmental cost report that is not separated at Bali Zoo has made the company unable to evaluate the efficiency of their resource utilization in managing the environment. Hence, this study proposes a solution to Bali Zoo in the forms of environmental cost classification and environmental cost report, which are based on the 2018 Annual Financial Statement of Bali Zoo. That environmental cost report can be used as a reference for the next years in order to ease Bali Zoo to comprehensively track their own environmental costs. It will also help the company to identify better opportunities regarding saving up resources. Additionally, Bali Zoo will be able to maximize their environmental management strategy and environmental management innovation in resulting the desirable environmental management performance in accordance to goals of the company.

The limitation of this research is only carried out on one of Bali Zoo's stakeholders, which is the Bali Zoo's management as a party that provides information from internal company perspective. In addition, the difficulty of getting access to financial reports from previous years also becomes a limitation of this study so that researchers cannot compare environmental costs that have occurred from year to year to see the comparison of environmental costs with environmental management performance at the Bali Zoo.

Future researchers are expected to be able to examine from the external perspective of Bali Zoo's stakeholders in connection with the company's environmental impact, such as visitors who directly experience the condition of the Bali Zoo environment or the community around the business location that has the potential to be affected by Bali Zoo operational activities every day. Future studies are expected to add research instruments such as observation to see how the actual practice of environmental management system occurs in the field. In addition, next researchers should further analyze environmental cost data for more than one year, so they can compare and evaluate the environmental cost and environmental management performance of Bali Zoo optimally.

\section{References}

Abdullah, M. W., \& Yuliana, A. (2018). Corporate Environmental Responsibility: An Effort To Develop A Green Accounting Model. Jurnal Akuntansi, XXII(03), 305-320. Retrieved from http://dx.doi.org/10.24912/ja.v22i3.390.

Ajayi, O. O., \& Ayodele, I. A. (2016). Knowledge and Practice of Environmental Management at Selected Ecotourism Destinations in Edo State. Journal of Tourism, Hospitality Adn Sports, 16, 22-32.

Almarri, K., \& Gardiner, P. (2014). Application of Resource-based View to Project Management Research: Supporters and Opponents. Procedia Social and Behavioral Sciences, 119, 437-445.

https://doi.org/10.1016/j.sbspro.2014.03. 049.

Ann, G. E., Zailani, S., \& Wahid, N. A. (2006). A Study on the Impact of Environmental Management System (EMS) Certification Towards Firms' Performance in Malaysia. Management of Environmental Quality: An International Journal, 17(1), 73-93. 
https://doi.org/10.1108/14777830610639 459.

Bali Zoo. (2018). Laporan Keuangan Tahunan Bali Zoo Tahun 2018.

Biswan, A. T., \& Widianto, H. T. (2019). Peran Beyond Budgeting Entry Scan untuk Mengatasi Permasalahan Penganggaran Sektor Publik, Jurnal Akuntansi Multiparadigma 10(2), 308-327. Retrieved from http://dx.doi.org/10.18202/jamal.2019.0 8.10018.

Cater, T., Prasnikar, J., \& Cater, B. (2009). Environmental Strategies and Their Motives and Resuls in Slovenian Business Practice. Economic and Business Review, 11(1), 55-74.

Christ, K. L., \& Burritt, R. L. (2013). Environmental management accounting: the signi fi cance of contingent variables for adoption. Journal of Cleaner Production, 41, 163-173. https://doi.org/10.1016/j.jclepro.2012.10. 007.

Clarkson, P. M., Fang, X. H., Li, Y., \& Richardson, G. (2010, March). The relevance of environmental disclosure for investors and other stakeholder groups: which audience are firms speaking to? In CMA Ontario Rotman School Accounting Research Seminars (pp. 143).

Creswell, J. W., \& Creswell, J. D. (2017). Research design: Qualitative, quantitative, and mixed methods approaches. Sage publications.

Ferreira, A., \& Moulang, C. (2010). Environmental Management Accounting and Innovation: an Exploratory Analysis. Accounting, Auditing \& Accountability Journal, 23(7), 920-948. https://doi.org/10.1108/09513571011080 180.

Hansen, D. R., \& Mowen, M. M. (2015). Cornerstones of Cost Management (3rd ed.). South-Western: Cengage Learning.

Hart, S. L. (1995). A Natural-Resource-Based View of The Firm. Academy of Management Review, 20(4), 986-1014.

Hsiao, T., Chuang, C., Kuo, N., \& Yu, S. M. (2014). Establishing attributes of an environmental management system for green hotel evaluation. International Journal of Hospitality Management, 36,
197-208.

https://doi.org/10.1016/j.ijhm.2013.09.0 05 .

Inoue, E., Arimura, T. H., \& Nakano, M. (2013). A new insight into environmental innovation: Does the maturity of environmental management systems matter? Ecological Economics, 94, 156163.

https://doi.org/10.1016/j.ecolecon.2013. 07.014 .

Iraldo, F., Testa, F., \& Frey, M. (2009). Is an Environmental Management System Able to Influence Environmental and Competitive Performance? The Case of the Eco-management and Audit Scheme (EMAS) in the European Union. Journal of Cleaner Production, 17, 1444-1452. https://doi.org/10.1016/j.jclepro.2009.05. 013.

Jalaludin, D., Sulaiman, M., \& Ahmad, N. N. N. (2010). Environmental Managament Accounting: An Empirical Investigation of Manufacturing Companies in Malaysia. Journal of Asia-Pacific Centre for Environmental Accountability, 16(3), 31-45.

Jasch, C., \& Savage, D. E. (2008). The IFAC International Guidance Document on Environmental Management Accounting.

Kang, Y., \& He, X. (2018). Institutional Forces and Environmental Management Strategy: Moderating Effects of Environmental Orientation and Innovation Capability. Management and Organization Review, 13(3), 577-605.

Le, T. T., \& Nguyen, T. M. A. (2019). Practice Environmental Cost Management Accounting: The Case of Vietnamese Brick Production Companies. Management Science Letters, 9, 105120. https://doi.org/10.5267/j.msl.2018.10.01 2.

Masanet-Llodra, M. J. (2006). Environmental management accounting: a case study research on innovative strategy. Journal of Business Ethics, 68(4), 393-408. https://doi.org/10.1007/s10551-0069029-1.

Nor, N. M., Bahari, N. A. S., Adnan, N. A., Kamal, S. M. Q. A. S., \& Ali, I. M. (2016). The Effects of Environmental Disclosure on Financial Performance in 
Malaysia. Procedia Economics and Finance, $\quad 35, \quad 117-126$. https://doi.org/10.1016/S22125671(16)00016-2.

Nwaiwu, N. J. (2018). Environmental Cost Disclosure and Financial Performance of Oil and Gas in Nigeria. International Journal of Advanced Academic Research, 4(2).

Indonesia, P. R. (2014). Peraturan Pemerintah Nomor 101 Tahun 2014 tentang Pengelolaan Limbah Bahan Berbahaya dan Beracun. Lembaran Negara RI Tahun 2014.

Rechkemmer, A., Connor, A. O., Rai, A., Sparks, J. L. D., Mudliar, P., Shultz, J. M., ... Sparks, J. L. D. (2016). A complex social-ecological disaster: Environmentally induced forced migration. Disaster Health, 3(4), 112120.

https://doi.org/10.1080/21665044.2016.1 263519.

Schaltegger, S., Viere, T., \& Zvezdov, D. (2012). Tapping environmental accounting potentials of beer brewing Information needs for successful cleaner production. Journal of Cleaner Production, 29-30, 1-10. https://doi.org/10.1016/j.jclepro.2012.02. 011.

Schiederig, T., Tietze, F., \& Herstatt, C. (2011). What is Green Innovation? A quantitative literature review (No. 63). Working Papers/Technologie-und Innovation management, Technische Universit? t Hamburg-Harburg.

Schultze, W., \& Trommer, R. (2012). The Concept of Environmental Performance and Its Measurement in Empirical Studies. Journal of Management Control, 22(4), $375-412$. https://doi.org/10.1007/s00187-0110146-3.

Stanojevic, M., Vranes, S., \& Gokalp, I. (2010). Green accounting for greener energy. Renewable and Sustainable Energy Reviews, 14(9), 2473-2491. https://doi.org/10.1016/j.rser.2010.06.02 0 .

United Nations Environment Programme. (2019). Letter from the Executive UNEP in 2019. Retrieved from https://www.unenvironment.org/annualr eport/2019/index.php.

Wagner, M., \& Schaltegger, S. (2004). The effect of corporate environmental strategy choice and environmental performance on competitiveness and economic performance: An empirical study of EU manufacturing. European Management Journal, 22(5), 557-572. https://doi.org/10.1016/j.emj.2004.09.01 3.

Wiguna, D. (2017). "Bali Zoo" Sabet Penghargaan Lembaga Konservasi Terbaik. Antara Online. Retrieved from https://www.antaranews.com/berita/6461 63/bali-zoo-sabet-penghargaan-lembagakonservasi-terbaik.

Zhong, L., Buckley, R. C., Wardle, C., \& Wang, L. (2015). Environmental and visitor management in a thousand protected areas in China. Biological Conservation, 181, 219-225. https://doi.org/10.1016/j.biocon.2014.11. 007. 